\title{
Climate Variability, Land-Use, Pastoral and Agropastoral Livelihoods in Arid and Semi-Arid Areas of Kenya
}

\author{
Amwata D.A., Nyariki D.M
}

\begin{abstract}
Kenya's arid and semi-arid lands (ASALs) are experiencing climate variability, especially rainfall and temperature alterations. Rainfall is recognised as one of the critical parameters influencing land-use dynamics and consequently livelihoods in the arid and semi-arid areas inhabited by pastoral and agropastoral communities. Climate variability influences the type of livestock kept, crops grown and diversity of livelihood options. To understand how climate variability and change contribute to land-use changes, questionnaire interviews, Focus Group Discussions and direct observations were used to obtain information from 98 and 100 households in Kajiado and Makueni Counties respectively. In addition, desk reviews were carried out on government reports, previous studies and publications. The data obtained were analysed through descriptive and inferential statistics. The study found out that land-use activities, land sizes, livestock numbers, type of crops grown and adaptation options vary across rainfall gradients and are some of the factors that determine if a household would diversify its farm and non-farm activities. However, there two production systems have shown some similarities in adaptation options such as migration and diversification. Therefore developments in the ASALs need to holistically adopt a systems approach to land management taking into consideration all existing land-use systems in the study area as a pre-requisite for sustainability of ASAL ecosystems.
\end{abstract}

Index Terms - climate change, pastoralism, rangelands and rural livelihoods.

\section{INTRODUCTION}

In Kenya, the arid and semi-arid lands (ASALs) constitute $80 \%$ of the total land surface area (Nyariki and Ngugi 2002; Amwata 2004) and has $30 \%$ of the national population and $50 \%$ of the national livestock population and vast amounts of untapped natural resources (ROK 2004; UNDP 2010). In terms of rainfall, the ASALs receive an annual precipitation of between $500 \mathrm{~mm}$ and $800 \mathrm{~mm}$ and lie within ecological zone $1 \mathrm{~V}$, with an extension to zone $\mathrm{V}$. The traditional land-use in the area has been pastoralism, minimal agriculture and dry season grazing (Farah, 1996; Campbell and Migot-Adhola, 1981).The land-use is controlled by climate, soil, technology, markets and customs (Nderitu et al.1999). Even though other biophysical and socio-economic factors interact together to influence the ecosystems and livelihoods

Amwata D.A., Department of Agriculture Sciences, South Eastern Kenya University, P.O. Box 170-90200, Kitui, Kenya

Nyariki D.M, Department of Business and Economics, Murang'a University of Technology, P.O. Box 85, Murang'a Kenya in the ASALs, rainfall prioritised given that it is the most critical and limiting factor in these areas. Rainfall patterns in these areas have historically dictated spatio-temporal variability in water, fodder and diseases, thus, influences mobility and settlement patterns justifying pastoralism as the more suitable livelihood (Swift 1988; Fratkin et al. 1999; Wasonga 2009; Wasonga et al. 2010).

While pastoralists have evolved their methods of managing climate risks over time, increasing population pressure, land-use changes and urbanisation have began to erode the coping mechanisms. Thus increased seasonal hunger through reduced livestock productivity and consequently a collapse in livestock prices. The relative terms of trade between livestock and grain have often rapidly turned against livestock during droughts (Wasonga et al. 2010) making the purchase of grains and other commodities significantly more difficult for the affected households, thereby increasing their vulnerability to food insecurity.

According to Focus Group Discussion and household surveys, 11 and 14 extreme weather events for Makueni and Kajiado Stratum respectively have been reported from 1980 to 2010 . For both counties, droughts occurred in $1983 / 1985$, $1993 / 1994$ and 2005 while heavy rains were reported in 1986/87 and 1997/1998. The drought events coincide with the lowest annual rainfall recorded in the Makueni meteorological stations. Similarly, in Kajiado Stratum, social surveys established that droughts were experienced in 1984 , 1990, 1991, 1994, 1996, 2005 and 2006. Heavy rains were recorded in 1997/1998, the El Nino period. Already, the annual rainfall is varied with distinct low and high amounts, and given the trend of global warming, it is expected that weather patterns will be altered, especially rainfall amounts, resulting in increased severity and frequency of extreme climatic events. It has been argued that the effects of climate variability and change will probably be most acute for pastoralists and agropastoralists, especially those in Africa, including Kenya (Wasonga et al. 2010). Climate risks interact with other stresses such as diseases, changing land tenure, sedentarising populations, increasing banditry, consequently promoting a vicious cycle of poverty. For pastoral populations, this scenario is aggravated by their low adaptive capacity, which, as opposed to more intensively managed systems, tends to evolve slowly in the face of change, thus increasing vulnerability to climate shock (Hulme et al., 2001). 


\section{MATERIALS AND METHODS}

To understand the interactions among climate variability, land-use changes and livelihoods, purposive sampling was first carried out to select the two ASAL counties based on whether they were mainly occupied by pastoralists or agropastoralists and similarities in terms of ecological zones. All the locations within the two counties were listed and eight locations were chosen randomly from each of the counties. In Kajiado Stratum, Loodikilani, Nkoile, Enkaroni, Enkorika, Olobelbel, Osilalei, Oloontulugum and Mashuru were chosen while Kiboko, Nguumo, Masongeleni, Kambu, Mtito Andei and Makindu and Kikumbulyu were selected for Makueni Stratum. Both primary and secondary data were collected. The primary data were collected through household surveys, direct observations and interviews. Information on land-use and ownership was obtained through household questionnaire interviews and Focus Group Discussions (FGD) with selected group of individuals who were believed to have a wealth of knowledge on the study area. The questionnaires addressed land-use changes, rainfall gradient and livelihood zones, land size and perceptions on climate variability. The rainfall levels obtained were categorised into two; those receiving less than $450 \mathrm{~mm}$ and those receiving more than $450 \mathrm{~mm}$ of rainfall. In addition, secondary data were collected from the Republic of Kenya relevant ministries, publications and scientific reports.

\section{RESULTS AND DISCUSSION}

\section{i) Climate Variability and Water Sources in the} Study area

The water sources in Kajiado Stratum were mainly boreholes, shallow wells, dams and pans. Whether a household uses a source of water depends entirely on rainfall. For instance, under conditions considered normal, that is when the area receives at least $60 \%$ of annual rainfall (Ndathi et al. 2011a), and households tend to use the dams and pans. As weather condition becomes severe, the dams and pans dry-up and households start to fetch water from the boreholes and shallow wells. However, the reliability of shallow wells for water is diminishing due to their proximity to the boreholes. Under severe drought, $70 \%$ of the households use boreholes and shallow wells while the remaining $30 \%$ use dams, pans, rivers, springs and piped water.

\section{ii) Link between Climate Variability and Land Size}

Land ownership status in the study area include communal, trust and individual ownerships. About $60.5 \%$ of the respondents own land individually and title deeds have been issued. Similarly, $37.5 \%$ own land communally or as group ranches, of which more than $50 \%$ of these households are in the process of sub-division while the remaining $1.7 \%$ were tenants. Approximately $84.2 \%$ of the privately owned lands were found in Makueni Stratum. The average land holding per household for the study area is presented in Table 2.1. The overall mean land size for the study area was 110 acres; however the mean land sizes varied between Kajiado and Makueni Counties. In Kajiado Stratum, the mean land size was 110 acres and that of Makueni was 17.63 acres. The large tracts of land in Kajiado Stratum were found in the agro-ecological zone VI or lowlands. These zones are unable to support farming activities due to their aridity, and consequently limited incentives for sub-division. Moreover, these households are predominantly livestock keepers, thus large tracts of land provide forage resources to the animals. The reverse was noted in Makueni Stratum where land sizes were relatively smaller in Zone V, with about $51 \%$ having land less than 10 acres. The likely explanation is that most of Makueni Stratum falls in AEZ V, which have potentials for agriculture, thus people have incentives to sub-divide land for intensive agriculture.

Table 3.1: Relationship between rainfall and land size in the study area

\begin{tabular}{|c|c|c|c|c|c|}
\hline \multirow{2}{*}{$\begin{array}{l}\text { Land size } \\
\text { in acres }\end{array}$} & \multicolumn{2}{|l|}{ Kajiado } & \multicolumn{2}{|l|}{ Makueni } & \multirow[t]{2}{*}{ Total } \\
\hline & $\begin{array}{l}>450 \text { to }>900 \mathrm{~mm} \\
\text { (semi-arid or Zone } \\
\text { V) }\end{array}$ & $\begin{array}{l}\quad<300 \text { to } \\
\leq 450 \mathrm{~mm} \text { (arid } \\
\text { or Zone VI) }\end{array}$ & $\begin{array}{l}>450 \text { to }>900 \\
\text { mm (semi-arid or } \\
\text { Zone } \mathrm{V})\end{array}$ & $\begin{array}{l}\quad<300-\leq 450 \\
\text { mm (arid or } \\
\text { Zone VI) }\end{array}$ & \\
\hline$\leq 10$ & 0 & 4 & 51 & 7 & 62 \\
\hline$>10$ to $\leq 20$ & 0 & 0 & 1 & 24 & 24 \\
\hline$>20$ to $\leq 50$ & 0 & 1 & 12 & 1 & 14 \\
\hline$>50$ & 0 & 93 & 0 & 4 & 97 \\
\hline Total & 0 & 98 & 64 & 36 & 198 \\
\hline
\end{tabular}

Table 3.1 shows the relationship between rainfall amounts and land sizes owned by the households. Climate variability is illustrated by variations in the amounts of rainfall received. In Kajiado Stratum, all the households who owned more than 50 acres of land were found in areas receiving annual rainfall of between less than 300 and $450 \mathrm{~mm}$ (arid areas). In contrast, the majority of households in Makueni Stratum (79.7\%) owned less than 10 acres and they were found in areas receiving rainfall of more than $450 \mathrm{~mm}$ (semi-arid areas). The probable reason for the disparity in land sizes is that in Makueni Stratum, rainfall is slightly higher hence land has relatively higher agricultural potential and as a result, many immigrants flock the area to buy or rent land leading to locals dividing land to smaller sizes. Furthermore, as the household sizes increase, members are allocated individual parcels of land. 
On the other hand, in Kajiado Stratum, predominantly pastoral, rainfall is very low with lower agricultural potential, thus households have limited incentives to divide land, and therefore, land is still owned as a clan. Ndathi et al. (2011b) noted that large tracks of land in pastoral households provide the privilege to practise mobility as a coping strategy for drought and the opportunity to maximise sparse forage resources in the ASALs. Almen (2000) notes that in coastal Kenya, rainfall gradient influenced population density and land sizes. Further, he found reported that in livestock millet zone characterised by low rainfall, population density was very low but land sizes were large. As well, on the coastal plains with slightly more rainfall have high population density resulting in smaller land sizes. Likewise, Williamson and Sabbath (1982) states rainfall is one of key determinants of the land size in Marshall Islands, northern Pacific.

iii) Relationship between Land-use activities and Rainfall in Kajiado and Makueni Counties

The land-use activities in the study area are linked to rainfall levels (Table 2.2). Generally, there are three livelihood zones in both counties; first livelihood zone is characterised by livestock keeping; second, marginal farming and lastly mixed farming. These are complemented by

Table 3.2: Rainfall and land-use activities in the study area

\begin{tabular}{lll}
\hline County & Rainfall $(\mathrm{mm})$ & Land-use activities \\
\hline Kajiado & $<300$ to $\leq 450$ & $\begin{array}{c}\text { Livestock keeping, charcoal burning and casual wages } \\
\text { Marginal mixed farming: livestock, maize, beans, fruits, vegetables, } \\
\text { Makueni }\end{array}$ \\
$\begin{array}{l}>450-900 \\
\text { green grams) }\end{array}$ \\
$\begin{array}{c}\text { Marginal mixed faming (livestock, maize, beans, fruits, vegetables, } \\
\text { green grams), charcoal burning, petty trade and casual wages }\end{array}$
\end{tabular}

$>450$ to $>900 \quad$ Marginal mixed farming (livestock, maize, beans, pigeon peas)
Also, Rosenzweig and Wolpin (1993) noted that climate related events such as droughts and floods indirectly influence the behaviour of households by pushing them toward livelihood options such as petty trading, shop-keeping and other alternatives whose income streams are lower on average, but less volatile than pastoralism. Besides, Wasonga et al. (2010) and Carter and Barrett (2006) argue that even if drought occurred only once in several years, the very threat of this shock is sufficient to keep poor households trapped in poverty as they pursue lower-return livelihoods as an inefficient means of managing their risks ex-ante.

Another aspect of non-farm diversification that was noted in the study area was migration. Climate variability (rainfall) has a negative influence on migration. According to $\mathrm{Mr}$. Salao, a village elder in Kajiado Stratum, 'the numbers of youths migrating during drought years are increasing. "My sons did not leave home in early 1990s, but since 2000, they have moved with their livestock and families almost every year due to poor rains. My two other sons work in Kajiado town as watchmen". Thus migration rates increased in years of low rainfall and severe droughts. From the surveys and FGDs, the years that were noted to have highest number of migration were 1984, 1988, 1998, 2000, 2003 and 2005. These years coincide with drought years reported in the alternative livelihoods, charcoal burning, casual wages and, petty trade. Table 3.2 shows that households in areas receiving low annual rainfall of less than or equal to $450 \mathrm{~mm}$ tend to diversify household activities to enhance household earnings. For instance, in Kajiado Stratum, in addition to such as charcoal burning and casual labour. A similar observation has also been noted in Makueni Stratum, where in addition mixed crop and livestock farming, households in low rainfall areas also engage in petty trade and casual labour. This finding is consistent with those of Little et al. (1999) which noted that in the lowlands of northern Kenya, where average rainfall is low (below $400 \mathrm{~mm}$ ), agricultural potential is very low, thus the region diversifies to wage labour and trading and or business as a means of enhancing household wellbeing. Similarly finding have been reported by Prah (1979) in Botswana, Webster (1979) in Malawi, Ezra and Gebre-Egziabher (2001) in Ethiopia, Deshingkar and Grimm (2004) in India, Mensah-Bonsu (2003) and Assan et al. (2009) in Ghana. livestock keeping, the households practise off-farm activities

Republic of Kenya. These observations are consistent with those of Waddington and Sabates-Wheeler (2003) who established that in resource poor areas; migration remains a last resort livelihood option and income source towards improvement in well-being. They further stated that where rural dry land communities are faced with risky environments, entire communities might follow circular migration routes.

The perceived effect of low rainfall and drought on migration is very high, $74.3 \%$ for Kajiado Stratum and 62.3 $\%$ for Makueni Stratum. Migration is employed as a survival and adaptive strategy against vulnerability to food insecurity associated with inadequate rainfall. The study also showed that more people migrate in drought years, and the year of first-migration for most of the respondents (58.9\%) coincided with those recorded by the Kenya Metrological Department as severe drought years in the southern rangelands of Kenya (climate, temperature and rain days data from 1965 to 2010). Migration results in disruption of socio-economic activities. For instance, under drought conditions, close to $61 \%$ of households in Kajiado Stratum and $26 \%$ in Makueni Stratum between 10 to 45 years migrate either in search of dry season grazing pastures or non-farm employment. This age group comprises children of school going age; thus adversely affecting school attendance. As a result, children from the ASALs cannot academically 
compete effectively with their counterparts from other parts of Kenya.

\section{iv) Climate Variability and Livestock Numbers}

Livestock is still a key resource in Kajiado and Makueni Strata and a major economic activity. However, livestock keeping is on the decline as a considerable number of households transform to agropastoralists. The growing commercialisation of the pastoral economy has encouraged livestock production for the market rather than pure subsistence. The major livestock types kept included cattle, sheep and goat, though other species such as donkey, pigs and camels are increasingly becoming popular due to the additional role they play. For example, the donkey provides transport for water during dry periods and products to markets for sale. Also, pigs have become an additional source of income as well as a way maximising refuse from the kitchen.

The production of the livestock sector is determined by rainfall levels, livestock population and pastoral dietary needs (Republic of Kenya (ROK) 1994). The long term trend of livestock population (mainly cattle, sheep and goats) in Kajiado Stratum depicts variations with rainfall levels (Figure 2.1). The cattle population crash corresponds to periods of reduced rainfall amounts. These periods of cattle population decline match the years of drought as recorded in 1983-84, 1992-94 and 2000. The likely explanation for the close link between rainfall and cattle numbers is that cattle require a lot of feed and when rainfall are very high, more forage and water resource are available, thus households tend to keep more cattle to maximise the available resources. However, when rainfall is low and more unpredictable, forage resources become limited and households prefer to keep small ruminants such as sheep and goats since they have less feed requirements. Besides, goats are mixed feeders and would utilise a wide range of forage resources.

The trends in the number of small ruminants (sheep and goat) show discernable changes with rainfall levels (Figure 3.1). There is a negative relationship between rainfall and the number of small ruminants. Years that had high rainfall variations showed an increasing trend in small ruminants as shown in 1990, 1995, 2001 and 2004. The likely explanation for this trend is that when rainfall increases and shows a more predictable trend, more households tend to keep more cattle than small ruminants. But, when rainfall is low and shows high variability, households revert to keeping more of small ruminants due their ability to withstand very harsh environments. For example, considerable decline in small ruminant population (crash) was noted in 1984, 1987/1988, 1996 and 2001. These periods corresponds to periods of drought reported during the focus group discussion, household surveys and meteorological department annual reports.

Similarly in Makueni Stratum, rainfall had a negative relationship with the number of small ruminants. The highest number of small ruminants was noted in periods of low rainfall amounts (1995, 2003 and 2005), while lowest small ruminant numbers were recorded in 1993, 1999 when rainfall amounts were at the highest. Furthermore, as mean annual rainfall becomes more varied, the numbers of the small ruminants have continued to rise from 1999 to 2006. The likely explanation is that the small ruminants are more adapted to harsh environment and can utilise the limited forage resources. In contrast, there was no relationship noted between rainfall and cattle numbers in Makueni Stratum. The probable reason could be that households in the county have limited land size to keep large number of cattle due to their large dietary requirements; hence even under high rainfall, the households are unwilling to increase number of cattle kept due to limitation of land sizes.

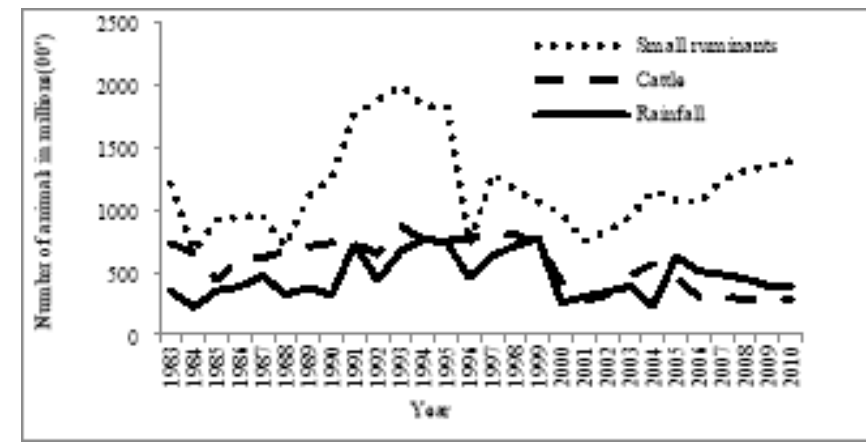

Figure 3.1: Linking rainfall and livestock numbers in Kajiado Stratum

Source of Data: KIPPRA (2010).

In understanding the influence of rainfall on the number of livestock, it is necessary to show how rainfall also influences forage resources, which determines the number of livestock. Figure 3.4 shows that rainfall has no influence on pasture availability and stocking rate (animals/ha). The mean annual rainfall for the period 1991 to 2010 has been highly variable with distinct high and low levels. On the same note, the numbers of animals kept per hectare have been on the decline irrespective of the rainfall levels. Taking into account the fact that the productive and carrying capacity of land is crucial to support grazing, thus a clear indication of land is already overburdened. Therefore, even with high rainfall levels, the soils are unable to support adequate pasture growth. Another issue is the decline in land holding per household due to sales and privatisation of land tenure have considerably interfered with traditional grazing areas and resources, and subsequently fewer animals per unit area.

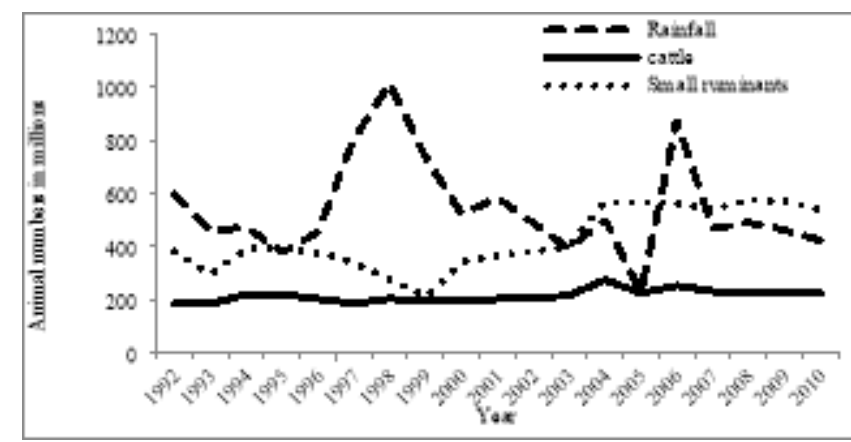

Figure 3.2: Relationship between rainfall and livestock numbers in Makueni Stratum

Source of Data: KIPPRA (2010); Ministries of 


\section{Agriculture and Livestock Development Annual Reports.}

Despite the fact that the number of animals per unit area has decreased, focus group discussions still stress livestock mobility as useful strategy for both households in Kajiado and Makueni Counties to cope with drought at different time of the year (Table 3.4.). The households in Kajiado Stratum move with their livestock as far as Mt. Kenya and Tanzania.

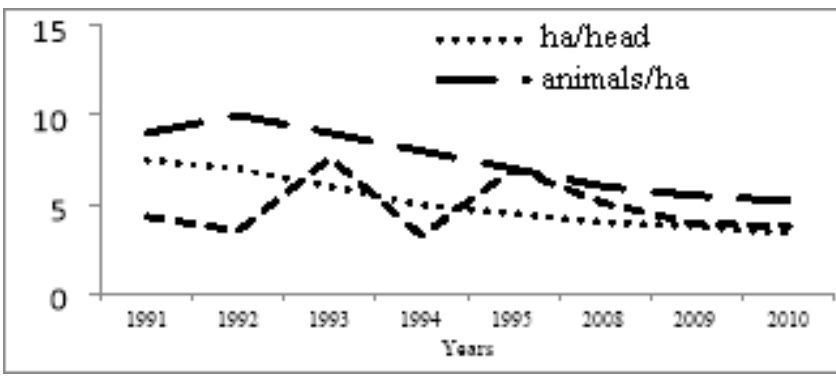

Figure 3.4: Relationship between rainfall and pasture availability in Kajiado Stratum

Source of Data: Kajiado Stratum Livestock Office Annual Report (2008; 2009; 2010); Kajiado, DWA, KEFRI and Makindu Meteorological Stations.

Table 3.4: Migration pattern for Kajiado and Makueni Counties

\begin{tabular}{|c|c|c|c|}
\hline Counties & $\begin{array}{l}\text { Normal } \\
\text { drought }\end{array}$ & $\begin{array}{l}\text { Moderate } \\
\text { drought }\end{array}$ & $\begin{array}{l}\text { Severe } \\
\text { drought }\end{array}$ \\
\hline Makueni & \begin{tabular}{l}
\multicolumn{1}{c}{ Yatta, } \\
Amboseli, \\
Tsavo
\end{tabular} & $\begin{array}{l}\text { National } \\
\text { parks and } \\
\text { reserves }\end{array}$ & \\
\hline Kajiado & $\begin{array}{l}\text { Surroundi } \\
\text { ng group and } \\
\text { private } \\
\text { ranches }\end{array}$ & $\begin{array}{l}\text { National } \\
\text { parks and } \\
\text { reserves }\end{array}$ & $\begin{array}{l}\text { Namang } \\
\text { a, Chyulu } \\
\text { hills, Gilgil } \\
\text { and } \\
\text { Tanzania }\end{array}$ \\
\hline
\end{tabular}

Migration results in disruption of socio-economic activities. Moreover, household socio-economic activities and weather conditions are intertwined. Under drought conditions, more than $60 \%$ of household members aged between 10-45 years were either out in search of dry season grazing grounds or job opportunities. This age group comprises the children of school going age; thus school attendance is adversely affected.

\section{in the Study area}

Growing of crops has become one of the livelihood strategies for the communities in the two counties of the study area. The crops that have persistently been grown in the study area include maize and beans and pigeon peas, which have been the main food crops. The crops grown in the study area can be classified into five:

1. Food crops: maize, sorghum and millet, beans, cowpeas, pigeon peas and green grams;

2. Horticultural crops - dudhi, karela, tuna, french beans, brinjals, kale, cabbages, mangoes, citrus, papaws and bananas were grown under irrigation for subsistence and export;

3. Root crops: cassava and sweet potatoes;

4. Industrial crops: coffee, cotton and wattle trees; and

5. Oil crops: castor, macadamia and sunflower

The numbers of crops grown have evolved with some new crops being introduced and old ones being abandoned. Although various crops were being grown in the county, their successes depend on the reliability and the distribution of rainfall. Crop farming is mostly subsistence-oriented but occasionally the produce is sold to purchase basic needs and wants. The types of crops grown depend on the rainfall levels and the agro-ecological zones (AEZ) (Table 3.5). From Table 3.5 , maize, beans and pigeon peas are the most common crops in both agro-ecological zones. This is because they are a staple food for the study area and also in most parts Kenya. The amount of rainfall influences the type of crops grown For example, cotton is only grown in the semi-arid areas while cereals such as cassava, sorghum and millet and fruit trees are increasingly being grown in the low rainfall areas or arid areas because of their drought tolerance. Also, FGD reported that rainfall was diminishing and becoming more unreliable. As a result, coffee is increasingly being replaced by drought tolerant root crops such as cassava, millet and sorghum. For instance, some households in Kibwezi were abandoning coffee in semi-arid areas, due to its high rainfall requirement. Also in this county, a few households use parts of their yard for horticulture which boosts household food production.

v) Climate Variability (Rainfall) and Crop Farming

Table 3.5: Relationship between the different types of crops and rainfall amounts

\begin{tabular}{|c|c|c|c|}
\hline Agro-ecological zone & County & County areas & Types of crops \\
\hline \multirow[t]{2}{*}{$\begin{array}{l}\text { Semi-arid } \\
(>450 \text { to }>900 \mathrm{~mm}\end{array}$} & Kajiado & $\begin{array}{l}\text { Toroka, Mashuru, Enkutoto, } \\
\text { Ilushon, Emashini }\end{array}$ & $\begin{array}{l}\text { Maize, beans, green grams, pigeon } \\
\text { peas fruits and vegetables }\end{array}$ \\
\hline & Makueni & $\begin{array}{l}\text { Makueni-, Makindu, Kiboko, } \\
\text { Kibwezi, Mtito Andei, }\end{array}$ & $\begin{array}{l}\text { Maize, beans, coffee } \\
\text { and pigeon peas } \\
\text { Cotton, green grams } \\
\text { millet and sorghum }\end{array}$ \\
\hline \multirow[t]{2}{*}{ Arid $(<300$ to $\leq 450 \mathrm{~mm})$} & Makueni & Masongeleni and Kambu & $\begin{array}{l}\text { Maize, beans, pigeon peas, cassava, } \\
\text { sorghum, millet }\end{array}$ \\
\hline & Kajiado & $\begin{array}{l}\text { Loodokilani, Elangata } \\
\text { Ordapoi, Oltepesi }\end{array}$ & Maize, beans and pigeon peas \\
\hline
\end{tabular}


A phenomenon that is also spreading quickly, especially around the larger towns in the area, is the construction of greenhouses made of a combination of mud, wooden bars, and plastic covers. The products are sold in the nearby towns while also lengthening the season during which a household has access to fresh vegetables, tomatoes and fruits, consequently enhancing vitamin intake. For Kajiado Stratum, cropping is slowly picking up and most of crops grown were retained, and in addition, fruits and vegetables were introduced to diversify the households' food sources.

vi) Interaction between Maize Crop and Rainfall in the Study area

To understand the interaction between crops and rainfall in the study area, maize was used as an example, given that it is a staple food in both counties. In addition, it provides $42 \%$ of the dietary intake in Kenya (World Resources Institute 2007). Besides, it is the worst hit compared to other cereals when rainfall becomes unreliable and unpredictable. Makueni Composite maize requires a seasonal rainfall of at least 250 mm (Mortimore and Wellard 1991 as quoted by Gichohi 2000b). This was therefore used as a threshold value for defining a bad rainfall season. Seasonal rainfall was divided into three classes, (1) bad seasons with rainfall less than 250 $\mathrm{mm}$; (2) fair seasons with a range of 250 to $350 \mathrm{~mm}$; and (3) good seasons with rainfall greater than $350 \mathrm{~mm}$. Figure 6.5 presents the distribution of rainfall years in terms of bad, fair and good in regards to maize production. Bad seasons occur characteristically in runs of 2 to 5 seasons resulting in severe food shortages. Analysis of the frequency of bad, fair and good seasons for each decade shows that 1980s had the highest percentage of good seasons, while the 2000s had the highest percentage of bad seasons (Figure 2.5). The results are compatible with those of Jaetzold and Schmidt (1982), Downing et al. (1988) and (Gichohi 2000a). These scholars do recognise that weather conditions experiences vary from decade to decade; and worsen from one decade to another.

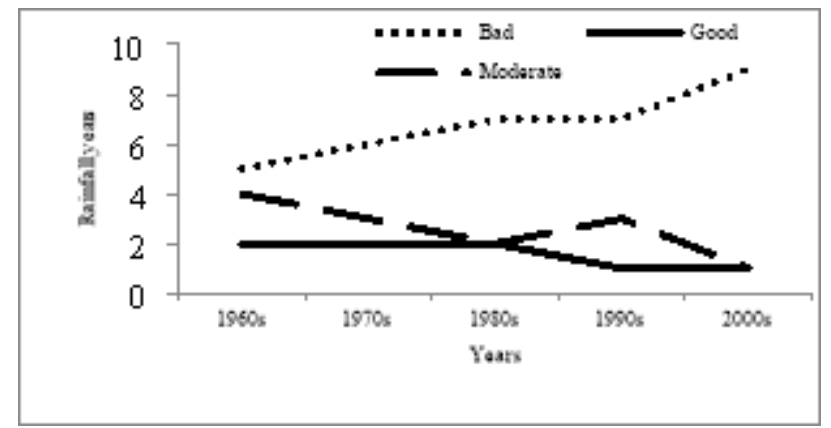

Figure: 3.5: Maize as a proxy for bad, moderate and good years for Makueni Stratum

Source of Data: KIPPRA (2010); Kajiado Stratum Livestock Office Annual Report (2008; 2009; 2010); Kajiado, DWA, KEFRI and Makindu Meteorological Stations.

Figure 3.6 shows the relationship between rainfall and total maize produced in Makueni Stratum. Maize production peaked in early 1990s but has since stagnated due to declining yields. De Groote et al. (2005) established that in early and late 1990s, maize production was at its peak, but a decline in trend has been evident from 2000 to 2005 . The lowest maize production was in 2005 and it coincides with the lowest mean annual rainfall received between 1992 and 2006. However, high rainfall amounts do not necessarily translate into high maize production. For example, the highest maize production of $11000 / \mathrm{m}^{2}$ was noted in 1993 when the mean annual rainfall was $458 \mathrm{~mm}$. This implies that rainfall level is not enough but rather other parameters including distribution, intensity remains critical. Again, rainfall levels were highest in 1997/1998, yet maize production still declined. Therefore, too much of rainfall have counter effect on crop production, salinity and soil PH. In support, Ketien et al. (2008) established that the decline in maize yields in Mtwapa and Kitale were related to rainfall variability and soil fertility. Also, Allen (1971) and Evans (1993) noted that in Kenya, maize production is influenced by rainfall, temperature, day length, solar radiation and humidity. He further emphasised that rainfall and its distribution remain fundamental in maize farming.

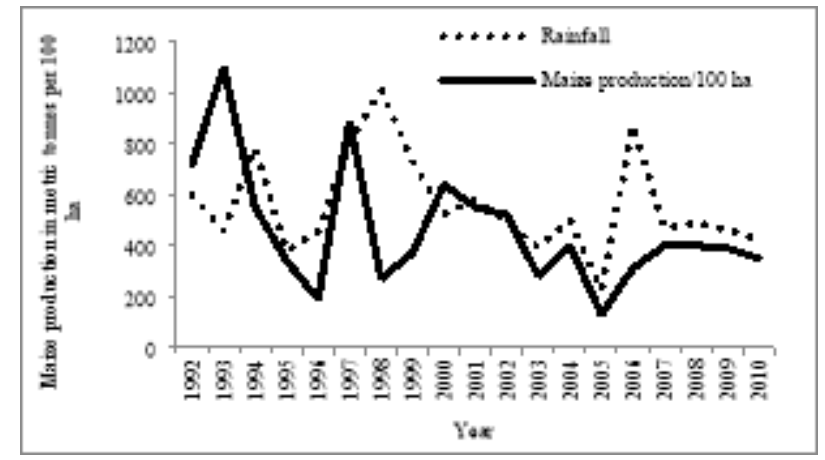

Figure 3.6: Relationship between rainfall and maize production in Makueni Stratum

Source of Data: KIPPRA (2010).

vii) Perception of causes of Land-use Change in the Study Area

In order to understand the land-use dynamics in the study area, households were asked to narrate how their land-use practices have evolved over time (Table 2.6). In Makueni Stratum, about $75.8 \%$ agreed that land-use had changed, $22.2 \%$ stated it had not and while the remaining (2.2\%) had no idea. The likely explanation for the latter was that these households were relatively new to the county and had lived in the county for less than six months. 
Table 3.6: Changes in land-use over time in Kajiado and Makueni Counties

\begin{tabular}{lllll}
\hline County & \multicolumn{4}{c}{ Change in land-use activities over time in the study area } \\
\hline Responses & No & Yes & No idea & Total \\
Kajiado & 44 & 54 & 0 & 98 \\
Makueni & 0 & 96 & 4 & 100 \\
Total & 44 & 150 & 4 & 198 \\
\hline
\end{tabular}

The factors that have contributed to land-use change include drought, rapid expansion of human population, poor government policies, and reduced forage for livestock and lack of water. These factors may act either singly or in combination to influence livelihoods. Households in both counties acknowledge that extreme weather event and in particular drought has significantly contributed to transformation of the various land-use practices in the study area. Besides, it is understood that drought does not act in isolation to influence land-use change, but in combination with other factors. Only $17.3 \%$ felt that drought singly contributed to land-use change (Table 3.7).

From the survey, drought associated with rainfall unreliability was cited by the respondents to be a cross-cutting factor determining the decisions on how to use farm and grazing land. Other factors cited include seed availability, soil fertility, land size, demand and market price, purpose of growing the crop, susceptibility to pests and diseases and wildlife menace. Close to $34.7 \%$ of the respondents stated that rainfall reliability, quality seeds and fertile soils were important followed by rainfall, land size and soil (30\%); and then rainfall and land size accounted for $21.3 \%$ of the responses.

Table 3.7: Factors contributing to land-use change in Kajiado and Makueni Counties

\begin{tabular}{lccc}
\hline Reasons for land-use change & County & Total \\
\cline { 2 - 4 } & Kajiado & Makueni & 42 \\
Drought and increased farming & 4 & 5 & 21 \\
Drought and high population & 16 & 3 & 12 \\
Drought, land size, population, lack of water & 9 & 0 & 2 \\
Drought, land size, population, reduced forage & 2 & 10 & 13 \\
Drought and changes in land ownership & 3 & 12 & 30 \\
Drought and government policy & 18 & 24 & 26 \\
Drought & 2 & 9 & 150 \\
Total & 54 & 9 & \\
\hline
\end{tabular}

Factors that were reported to influence the grazing land were rainfall reliability, breed of cattle, drought, milk production, water availability, pasture, land availability, land size, purpose for keeping the livestock and susceptibility to diseases and parasites. Approximately, $46.5 \%$ of the responses remarked that water, pasture and land remains the most critical parameter, followed by land size, breed and rainfall $(24.2 \%)$; purpose, breed and susceptibility to diseases $(13.6 \%)$, while rainfall in isolation contributed the least $(1 \%)$.

When the households in the two counties were asked on the factors they would consider in selecting non-farm activities. Majority $(70.2 \%)$ mentioned location was very important especially with business related ventures and rentals; followed by those who would not put any specific consideration $(23.2 \%)$, while $4.1 \%$ and $2.5 \%$ would consider climate related issues and purpose of the land-use respectively.

\section{viii) Climate Variability and Household Herd Sizes}

The number of livestock owned in terms of Livestock Tropical Units (TLU) in the two counties varied greatly. The mean herd size for Kajiado Stratum was 33.83 TLU compared to 8.9 TLU for Makueni. In addition, it was noted that livestock numbers in areas receiving less than $450 \mathrm{~mm}$ of rainfall were more or less similar in both counties. In Makueni Stratum, households owning less than 10 TLU were the majority under the two different rainfall regimes (Table 2.8). This was followed by 10-20 TLU, 20-30 TLU and lastly more than 30 TLU. The likely reason for this trend is that these areas have slightly higher potential for agriculture than areas receiving less than $450 \mathrm{~mm}$ of rainfall; hence there has been an influx of people leading to increased cultivation and more demand for agricultural land, thus limiting the space available for livestock grazing. For Kajiado Stratum, households owning more than 30 TLU were the majority while those having 1-10 TLU were the least. This can be explained by the fact that even though land has been sub-divided in Kajiado Stratum, most households still own land as a group, which still allows for vast areas for grazing. Therefore, livestock keeping is central to the livelihoods of these households.

In support, several studies have shown that livestock numbers are driven by rainfall via its direct effects on vegetation (Poshiwa et al., 2011; De Leeuw et al., 1984). They affirm that rainfall fluctuations have a role to play in livestock dynamics, both in numbers and distribution. According to Poshiwa et al. (2011), rainfall, primary production and cattle density are interlinked in southeastern lowveld of Zimbabwe. Similarly, De Leeuw et al. (1984) noted that estimates of livestock carrying capacity were usually derived directly from rainfall factors. He further stated that the average carrying capacity increases from about 7ha/TLU in the south of Kajiado Stratum where annual 
rainfall is $300 \mathrm{~mm}$ to about $3 \mathrm{ha} / \mathrm{TLU}$ in the north where the average rainfall is $550 \mathrm{~mm}$.

Table 3.8: Relationship between rainfall and livestock numbers

\begin{tabular}{|c|c|c|c|c|c|c|}
\hline \multirow[t]{2}{*}{ County } & \multirow[t]{2}{*}{ Rainfall amounts } & \multicolumn{5}{|c|}{ Livestock Numbers in TLU } \\
\hline & & $0 \leq 10$ & $>10 \leq 20$ & $>20 \leq 30$ & $>30$ & Tota \\
\hline \multirow[t]{2}{*}{ Kajiado } & Less than or equal to $450 \mathrm{~mm}$ & 5 & 17 & 19 & 19 & 60 \\
\hline & More than $450 \mathrm{~mm}$ & 1 & 6 & 25 & 25 & 38 \\
\hline \multirow[t]{2}{*}{ Makueni } & Less than or equal to $450 \mathrm{~mm}$ & 15 & 7 & 2 & 1 & 25 \\
\hline & More than $450 \mathrm{~mm}$ & 52 & 14 & 5 & 4 & 75 \\
\hline
\end{tabular}

ix) Climate Variability (Rainfall) and Household Size

(57.4\%) of households in the study area had household sizes

The mean household sizes for Kajiado and Makueni were 4.76 and 4.17 adult equivalents respectively. The majority

Table 3.9: Relationship between rainfall and household sizes in Kajiado and Makueni Counties

\begin{tabular}{|c|c|c|c|c|c|c|}
\hline & & $0 \leq 3$ & $>3 \leq 6$ & $>6 \leq 9$ & $>9$ & Total \\
\hline \multirow[t]{2}{*}{ Kajiado } & Less than or equal to $450 \mathrm{~mm}$ & 10 & 34 & 16 & 0 & 60 \\
\hline & More than $450 \mathrm{~mm}$ & 9 & 20 & 6 & 2 & 37 \\
\hline \multirow[t]{2}{*}{ Makueni } & Less than or equal to $450 \mathrm{~mm}$ & 5 & 13 & 7 & & 25 \\
\hline & More than $450 \mathrm{~mm}$ & 22 & 46 & 7 & & 75 \\
\hline Total & & 46 & 113 & 36 & 2 & 197 \\
\hline
\end{tabular}

x) Climate Variability (Rainfall Amounts) and Household Food Security

Table 2.10 presents the results of the descriptive analysis associated with the rainfall amounts and household food security. The analysis is disintegrated by the rainfall and land-use type in the study area. In general, $57.1 \%$ of the households in the study area were food secure while the remaining $42.9 \%$ were food insecure. Considering individual counties, households in Kajiado Stratum were more vulnerable to food insecurity with VFI of 0.59 than Makueni Stratum that had a VFI of 0.27. Rainfall was found to influence household vulnerability to food insecurity. For instance, in Kajiado Stratum, majority $(84.5 \%)$ of the food insecure households were found in areas receiving less than

$450 \mathrm{~mm}$ of rainfall. The reverse was noted in Makueni Stratum where a majority of the food secure $(76 \%)$ were found in areas with more than $450 \mathrm{~mm}$ of rainfall.

Even though a study by Amwata (2004) did not take into consideration climate variability or rainfall parameters, it noted that agropastoral and pastoral household vulnerability to food insecurity were 0.2 and 0.6 respectively. The current study establishes that the vulnerability of agropastoral households to food insecurity is 0.27 while that of pastoral households being 0.59. Comparing the findings of Amwata and the current study, vulnerability of agropastoralists has increased with seven $\%$ and that of pastoralists has decreased by one $\%$.

Table 3.10: Relationship between rainfall and household food security in the study area

\begin{tabular}{lllll}
\hline County & Rainfall amounts & \multicolumn{2}{c}{ Household food security status } \\
& & Food insecure & Food secure \\
\hline Kajiado & Less than or equal to $450 \mathrm{~mm}$ & 49 & 14 & 26 \\
& More than $450 \mathrm{~mm}$ & 9 & 16 & 35 \\
Makueni & Less than or equal to $450 \mathrm{~mm}$ & 9 & 57 & 25 \\
\multirow{2}{*}{ Total } & More than $450 \mathrm{~mm}$ & 18 & 113 & 75 \\
\hline
\end{tabular}

\section{CONCLUSION AND POLICY IMPLICATION}

Climate variability, specifically rainfall remains a critical factor influencing land-use systems and livelihood strategies in the ASALs. Areas with semi-humid to semi-arid climate attract different types of crops including horticulture thus pressure for fragmentation of land into smaller pieces in these agro-ecological zones. As more households revert to cultivation, less land is available for grazing, leading to reduction in cattle numbers but with increase in small ruminants such as sheep and goats that are able to withstand harsh climatic conditions. The study shows that climate factors such as rainfall influences farm-based and household factors. For example, households located in areas receiving high rainfall tend to have smaller land sizes than their counterparts in low rainfall areas. Also, households located in arid areas tend to keep more livestock than those in sub-humid to semi-arid areas due to availability of large tracks of land for grazing. As well, rainfall influences the type of crops grown in each of the county. Makueni Stratum that is 
relatively wet has options for growing food crops, root crops, oil crops and horticultural crops. This was not the case with Kajiado Stratum that had limited ability to grow horticultural crops.

In response to the changing climatic conditions like drought, both pastoral and agropastoral households have continued to devise survival strategies in isolation, without taking into consideration the interaction among these different production systems. However, these production systems have shown some similarities in adaptation options such as migration and diversification. Therefore developments in the ASALs need to holistically adopt a systems approach to land management taking into consideration all existing land-use systems in the study area as a pre-requisite for sustainability of ASAL ecosystems.

\section{REFERENCES}

[1]A.Y. Allen, 1971 "The influence of agronomic factors on maize yields in western Kenya, with special reference to time of planting". PhD Thesis, University of East Africa, Uganda.

[2]E. Almen, 2000, "The politics of land rights and squatting in coastal Kenya. A report from the research programme. The political and social context of structural adjustment in Africa". Ministry of Lands, Nairobi, Kenya.

[3]D.A. Amwata, 2004 "Effects of communal and individual land tenure systems on land-use and food security in Kajiado Stratum, Kenya". MSc Thesis, University of Nairobi, Kenya.

[4]J. Assan, C. Caminade and F. Obeng, 2009,. Environmental variability and vulnerable livelihoods: Minimising risks and pptimising opportunities for poverty alleviation. Journal of International Development, 21(3):403-418.

[5]D. Campbell, and S.E. Migot-Adholla, 1981, "The development of Kenya's semi-aridlands". Occasional Paper 36, Institute for Development Studies, University of Nairobi, Kenya.

[6]M. Carter, and C. Barrett, 2006, "The economics of poverty traps and persistent poverty: An asset-based approach". Journal of Development Studies, 42:178-199.

[7]H.. De Groote, G. Owour, C. Doss, J. Ouma, L. Muhammad and K. Danda, 2005, "The maize green revolution in Kenya revisited". Electronic Journal of Agricultural and Development Economics, 2:32-29. www.ftp.fao.org/.

[8]P.N. De Leeuw, B.E. Grandin and S. Bekure (nd), "Chapter 2: Introduction to Kenyan rangelands and Kajiado District". ILRI, Nairobi, Kenya. www.fao.org/wairdocs/ilri/.

[9]P. Deshingkar, and S. Grimm, 2004, "Voluntary Internal Migration". An update. ODI, London, United Kingdom.

[10] T.E., Downing, D.N. Mungai and H.R Muturi, 1988, "Drought climatology and development of the climatic scenarios". In Parry, M.L., T.R. Carter and N. Konijn (eds). The impact of climatic variation on agriculture, Vol. 2: Assessments in semi-arid regions: 149-174. Kluwer Academic Publishers, Dordrech, The Netherlands.

[11] L.T. Evans, 1993, "Crop evolution, adaptation and yield". Cambridge University Press, Great Britain, UK.

[12] M. Ezra, and K. Gebre-Egziabher, 2001, "Rural Out-migration in the drought prone areas of Ethiopia: A multilevel analysis". International Migration Review, 35:3.

[13] K.O. Farah, 1996, "Management and development of the arid communal rangelands of northeastern Kenya: An analysis of past and present". The African Pastoral Forum, Working Series 7, PINEP, University of Nairobi, Kenya.Fratkin, E.M., E. Roth and M. Nathan (1999). When nomads settle: Commoditization, nutrition and child education among Rendille pastoralists. Current Anthropology, 40(5):729-735

[14] F.N. Gichohi, (2000a). Makueni Stratum profile: Rainfall variability 1950-1997. Dryland Research Working Paper 2. Crewkerne Somerset, United Kingdom.

[15] F.N. Gichohi, 2000b, "Makueni Stratum Profile: Farm development 1946-1999". Drylands Research Working Paper 1. www.drylandsresearch.org/uk.

[16] M. Hulme, R. Doherty, T. Ngara, M. New, and D. Lister, 2001, "African climate variability and change: 1900-2100". Climate Research, 17:145-168.
[17] R. Jaetzold, and H. Schmidt, 1982, "Farm management handbook of Kenya, Vol. IIC. Eastern Province". Ministry of Agriculture and Livestock Development and Marketing, Nairobi, Kenya.

[18] P.K., Ketien, E.C. Kipkorir and P. Omondi, 2008, "Modelling effects of climate variability and change on maize production in Kenya. A case study of two agro-ecological zones". Kenya Agricultural Research Institute, Mtwapa, Kenya.

[19] KIPPRA (Kenya Institute of Public Policy Research and Analysis), 1999, Kenya agricultural sectoral data compendium. www.kippra.org/.

[20] P.D., Little, B. Cellarius, C. Barrett and D.L. Coppock, 1999, "Economic diversification and risk management among East African herders: A preliminary assessment and literature review". GL-CRSP Pastoral Risk Management Project Technical Report 02/99. Utah State University, Logan.

[21] Mensah-Bonsu, 2003, "Migration and Environmental Pressure in Northern Ghana". PhD Thesis, Tinbergen Institute, Vrije Universiteit, Amsterdam, The Netherlands.

[22] A.J.N, Ndathi, M.M. Nyangito, N.K.R. Musimba and B.N. Mitaru, 2011a, "Climate variability and dry season ruminant livestock feeding strategies in south eastern Kenya". Livestock Research for Rural Development, 23(9):2011.

[23] A.J.N, Ndathi, M.M. Nyangito, N.K.R. Musimba and B.N. Mitaru, 2011 , "Enhancing output oriented livestock improvement strategies in the drylands of Kenya". Livestock Research for Rural Development, 23(6):2011.

[24] G., Nderitu, C. Handa and J. Macharia, 1999, "Wetland biodiversity in Kajiado Stratum, Kenya". Swedish Agency for research Cooperation with developing countries (SAREC), RPSUD Project.

[25] D.M. Nyariki, and R.K. Ngugi, 2002, "A review of African pastoral production system: Approaches to their understanding and development". Journal of Human Ecology, 13(3):137-250.

[26] V.A., Orindi, A. Nyong and M. Herrero, 2006, "Pastoral livelihood adaptation to drought and institutional interventions in Kenya". Human Development Report Office, Occasional Paper 54.

[27] X., Poshiwa, I.M.A, Heitkonig, K. Murwira, E.C. Van lerland and H. Prins, 2011, "Rainfall, primary production and cattle density in southeastern lowveld of Zimbabwe". 8th Annual Savanna Science Networking Meeting, 8-12th March, 2010, South Africa.

[28] K. K. Prah, 1979, "Some sociological aspects of drought. In proceedings of the symposium on drought in Botswana. 5th-8th June 1978". Botswana Society in Collaboration with Clark University Press.

[29] N. Rass, 2006, "Policies and strategies to address the vulnerability of pastoralists in sub-Saharan Africa". Working Paper Series No. 37 for pro-poor livestock policy initiative (PPLPI)

[30] ROK, 2004, "National policy for sustainable development of the arid and semi-arid lands of Kenya."Nairobi, Kenya.

[31] ROK, 1994, "Populations and housing census". Central Bureau of Statistics, Government Printer, Nairobi, Kenya.

[32] M.R. Rosenszweig, and K.I. Wolpin, 1993, "Maternal expectations and ex-post rationalizations: The usefulness of survey information on the wantedness of children". Human Resources, 28(2):205-229.

[33] J. Swift, 1988, "Major issues in pastoral development with special emphasis on selected African countries". FAO Rome, Italy.

[34] United Nations Development Programme (UNDP), 2010, "Kenya national disaster profile". Enhanced Security Unit UNDP, Nairobi, Kenya. www://mirror.undp.org/kenya/.

[35] H. Waddington, and R. Sabates-Wheeler, 2003, "How does poverty affect migration choice? A review of literature". Development Research Centre on Migration, Globalisation and Poverty, Working Paper T3. University of Sussex, United Kingdom.

[36] V.O. Wasonga, J. van de Steeg, R. Ouma, A. Mude, 2010, "Risk management and adaptations options for pastoral and agropastoral systems in east and central Africa: A review paper on uncertainty in current seasonal rainfall and future climate variability and change". ILRI, Nairobi, Kenya.

[37] V.O. Wasonga, 2009, "Linkages between land-use, land degradation and poverty in semi-arid rangelands of Kenya. The case of Baringo County". Ph.D Thesis, University of Nairobi, Kenya.

[38] J.B. Webster, 1979, "Drought and Migration: The Lake Malawi Littoral as a region of refuge". In M.T. Hinchey (ed), Botswana Drought Symposium, The Botswana Society, Botswana.

[39] Williamson, and M.D.Sabbath, 1982, "Island population, land area, and climate: A case study of the Marshall Islands". Human Ecology, 10(1):71-84

[40] World Resources Institute, 2007, "Nature's Benefits in Kenya. An atlas of ecosystems and human well-being". Washington D.C and Nairobi. 
The authors recognise the contribution of three field assistants who participated in data collection; the Livestock and Veterinary staff from Ministry of Agriculture, Livestock, Fisheries and Cooperatives; Kenya Meteorological Stations in Makindu and Kajiado Stations for availing secondary data and identifying the champions and institutions to be contacted for the study. We are grateful to Charles Ikutwa, University of Nairobi, for providing technical and logistical support for data collection and analysis. A special thank you to the Stockholm Environment Institute - Africa Centre, for financing and providing technical inputs to in this research.

Authors Profile1. Dr Dorothy Akinyi Amwata, BSc, MSc, Ph.D.

(University of Nairobi, Kenya)Dr Amwata is a Rangeland Eco-Sociologist and Senior Lecturer, Department of Range and Wildlife Sciences, South Eastern Kenya University. She is specialised in dryland/rangeland management, ecosystem assessments, agriculture and food security, rangeland and natural resource policy, and ecosystem monitoring and evaluation. She has carried out research and worked for close to two decades on climate change, conservation of biodiversity, land degradation, climate adaptation, resilience and mitigation, monitoring and evaluation of projects, project appraisal, and planning, management and implementation.

2. Prof. Dickson Mong'are Nyariki, BSc, MSc (University of Nairobi, Kenya), Ph.D. (University of Reading, UK). Prof Nyariki a Professor specialised in Agricultural Economics with a bias towards dry-land resources and food security. He is currently Vice Chancellor of Murang'a University of Technology. He has carried out numerous consultancies and research on dry-lands and published more than 100 journal articles, book chapters, books, and refereed conference proceedings. Prof. Nyariki has coordinated regional projects on food security, livestock production, pastoralism and water harvesting. He has taught at various universities for more than 30 years, and supervised more than 40 postgraduate projects. 